\section{INTEGRATING MULTIMEDIA LEARNING THEORY IN ASSISTIVE COURSEWARE FOR LOW VISION LEARNERS}

\author{
A. Nurulnadwana* ${ }^{*}$ A. M. Ariffin ${ }^{b}$, S. Siti Mahfuzahb \\ aFaculty of Business and Management, Universiti Teknologi MARA, \\ Malaysia \\ bSchool of Multimedia Technology and Communication, Universiti \\ Utara Malaysia, Malaysia
}

Article history

Received

15 June 2015

Received in revised form

1 October 2015

Accepted

13 October 2015

*Corresponding author raiqraif@gmail.com

\section{Graphical abstract}

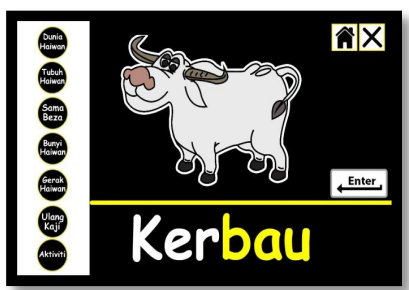

\begin{abstract}
This paper reports an ongoing study regarding the development of Assistive Courseware (AC) that is specifically designed to cater the needs of low vision learners in learning activities. Currently, as reported in the previous studies, low vision learners are facing various difficulties in their learning activities particularly in terms of information accessibility, navigationability, and pleasure. Previous literatures also state that, most of the available courseware means too little to them especially in terms of content presentation. Therefore, this study attempts to solve the problem by developing an AC which is named as AC for Low Vision Learners (AC4LV). The AC was developed by utilizing Multimedia Learning Theory as guidance. In addition, three basic steps, which are pre-production, production, and post-production have been utilized in developing the AC. As a result, an AC4LV based on Multimedia Learning Theory was successfully produced. Future works of this study is to test the experience of using AC4LV among the low vision learners particularly on primary school children from age nine to twelve.
\end{abstract}

Keywords: Assistive Technology (AT), Assistive Courseware (AC), low vision learners, Multimedia Learning Theory

\begin{abstract}
Abstrak
Kertas kerja ini membincangkan kajian berterusan berkenaan pembangunan Assistive Courseware $(A C)$ yang direkabentuk secara khusus bagi membantu memenuhi keperluan pelajar-pelajar berpenglihatan terhad dalam aktiviti pembelajaran mereka. Ketika ini, seperti yang dinyatakan dalam kajian-kajian lepas, pelajar-pelajar berpenglihatan terhad sedang menghadapi pelbagai kesukaran dalam aktiviti pembelajaran mereka terutamanya dari segi keupayaan capaian maklumat, keupayaan navigasi, dan keupayaan keseronokan. Literasi terdahulu juga menyatakan bahawa kebanyakkan koswer sedia ada kurang memberi makna kepada mereka terutamanya dari segi persembahan kandungan. Oleh itu, kajian ini berusaha untuk menyelesaikan masalah tersebut dengan membangunkan sebuah AC yang dinamakan sebagai Assistive Courseware for Low Vision (AC4LV). AC dibangunkan dengan menggunakan Teori Pembelajaran Multimedia sebagai panduan. Lanjutan dari itu, tiga langkah asas iaitu prapengeluaran, pengeluaran, dan pasca-pengeluaran telah digunakan dalam membangunkan AC. Hasilnya, sebuah AC4LV berasaskan Teori Pembelajaran Multimedia telah berjaya diterbitkan. Kajian ini akan diteruskan pada masa hadapan untuk menguji pengalaman pengguna di kalangan pelajar-pelajar berpenglihatan terhad terutamanya kanak-kanak sekolah rendah dari umur sembilan hingga dua belas tahun.
\end{abstract}

Kata kunci: Assistive Technology (AT), Assistive Courseware (AC), pelajar-pelajar berpenglihatan terhad, Teori Pembelajaran Multimedia

(C) 2016 Penerbit UTM Press. All rights reserved 


\subsection{INTRODUCTION}

Low vision learners are not similar with sighted learners. With the restrictions in their seeing, low vision learners have to fully utilize their other senses in their learning activities to compete with their sighted peers. Sorrowfully, most of the learning materials do not support them. By utilizing similar learning materials (i.e. text book, and typical courseware) with sighted students, and assisted with Assistive Technology (AT) (i.e. Close Circuit Television (CCTV), magnifying glass, screen reader, and screen magnification) [1] were actually problematic for them at most of the time [2] For the reason, they do not want to look different between their sighted peers and sometimes they also missing the equipments [1]. An observation conducted at Special Primary School of Visual Impairment, Penang Malaysia found that the low vision learners have to highly concentrate on the audio in order to get the information displayed on the online typical courseware (Figure 1). All this factors make their learning activities too complicated and have no pleasure.

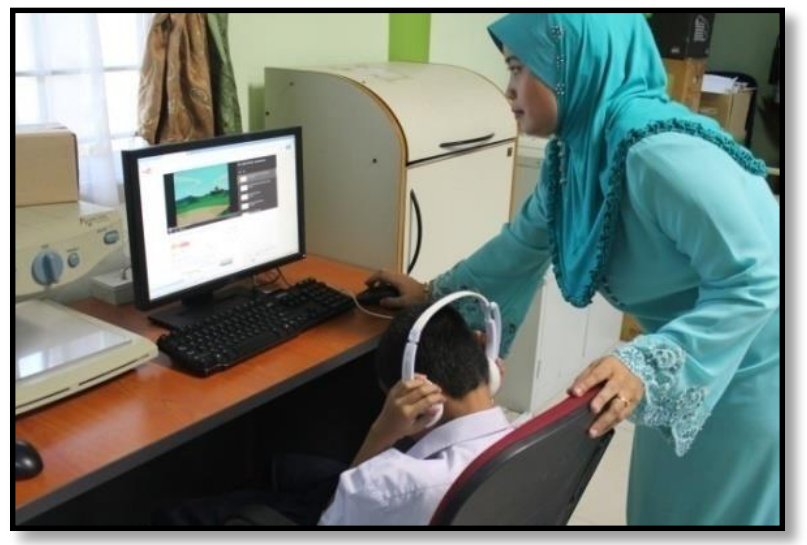

Figure1 Low vision learner using online typical courseware with the teachers' help

Most of the applications created to assist them in learning are in the form of software and hardware [3] [4] which is also known as assistive learning tools [5]. Also, most of this type of technologies requires the low vision learners to have technical skill to operate the functions. This is totally not appropriate to low vision learners particularly children to learn at their own pace. Furthermore, available content application means too little to them. This is because most of the content applications are created for fully sighted students. As most of the fully sighted students are visual learners [6] compared to low vision, they are audible learners. With the crowded page, iconic menus, fancy font face, and unsuitable font size and animations the low vision learners face difficulties to learn and finally getting frustrated [1]. Also, previous studies [7], [4], [8] related to comparative studies indicates that courseware that specifically designed to cater the needs of low vision learners in learning particularly in terms of information accessibility, navigation ability, and pleasure aspects is highly lacking. In fact, this three aspects is the main problems that currently faced by the low vision learners [1]. Therefore, the objective of this study is stated below:

(i) to identify the needs of low vision learners in learning,

(ii) to review the previous literatures related to Multimedia Learning Theory, and

(iii) to develop a courseware that is specifically designed to cater the needs of low vision learners based on Multimedia Learning Theory which is named as AC4LV.

Having identified the needs of low vision learners in learning, it was not significance for this study to not refer to any learning theories prior to develop the courseware since learning theories act as the root in developing any instructional materials including courseware. Of many types of learning theories, Multimedia Learning Theory proposed by [9] is considered as one of the significant learning theories. Prior to develop the AC4LV this study provides some reviews and elicited studies related to the intended theory, which is discussed in the following subsection.

\subsection{Reviews on Multimedia Learning Theory}

With the work carried out by Sweller's Cognitive Load Theory, Pavio's Dual-Coding Theory, and Baddeley's Working Memory Model [10], [11], [12] a framework called Cognitive Theory of Multimedia Learning as presented in Figure 2 has been proposed.

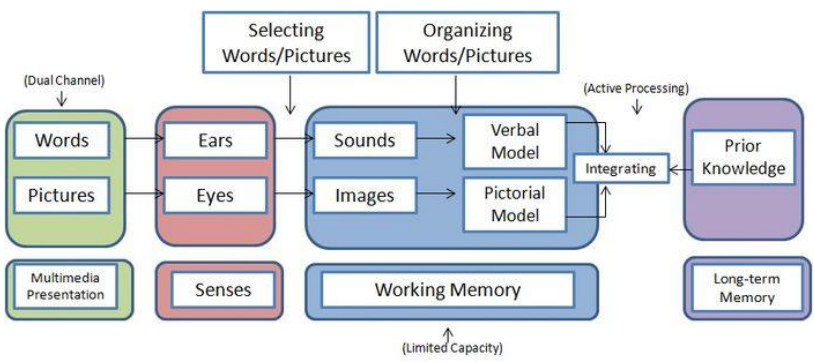

Figure 2 Framework for Cognitive theory of Multimedia Learning

This model focuses on auditory/verbal channel and visual pictorial channel. As addressed by [10], [11], [12], [13] that this model has been developed based on three hypotheses below:

i) Information of visual and auditory is process via different channels.

ii) Each different channel is limited in its ability to process the information.

iii) The channels of processing information are an active cognitive process which designed to construct coherent mental representations.

Mayer, Heiser, and Lonn (2001) and Mayer (2010) also detail the model into five steps, including (i) selecting relevant words for processing in verbal 
working memory, (ii) selecting relevant images for processing in visual working memory, (iii) organizing selected words into a verbal mental model, (iv) organizing selected images into visual mental model and (v) integrating verbal and visual representations as well as prior knowledge.

Besides, Mayer and his friends have investigated the nature and effects of multimedia presentation to human being [1 1], [12], [13], [14]. From that they come out with thirteen principles together with the sample example of practical application (Table 1).

Table 1 Principles of Multimedia Learning Theory

\begin{tabular}{|c|c|}
\hline Principles & $\begin{array}{l}\text { Examples of Practical } \\
\text { Applications }\end{array}$ \\
\hline $\begin{array}{l}\text { Multimedia Principle: } \\
\text { Students learn better } \\
\text { from words and pictures } \\
\text { rather than words alone. }\end{array}$ & $\begin{array}{l}\text { Combination of block of text } \\
\text { with still image or animation } \\
\text { on a screen is more efficient } \\
\text { rather that oral text or } \\
\text { graphic alone. }\end{array}$ \\
\hline $\begin{array}{l}\text { Spatial Contiguity } \\
\text { Principle: } \\
\text { Student learns better } \\
\text { when the combination } \\
\text { of words and pictures on } \\
\text { the page or screen are } \\
\text { presented near rather } \\
\text { than far from each } \\
\text { other. }\end{array}$ & $\begin{array}{l}\text { Placing the text under the } \\
\text { image is sufficient. However } \\
\text { placing the text within image } \\
\text { is more effective. }\end{array}$ \\
\hline $\begin{array}{l}\text { Temporal Contiguity } \\
\text { Principle: } \\
\text { Student learns better } \\
\text { when combination of } \\
\text { words and pictures that } \\
\text { are presented } \\
\text { simultaneously rather } \\
\text { than successively. }\end{array}$ & $\begin{array}{l}\text { When presenting text and } \\
\text { image, they should be } \\
\text { presented simultaneously, } \\
\text { but when presenting } \\
\text { animation and narration the } \\
\text { use of them is more coincide } \\
\text { meaningfully. }\end{array}$ \\
\hline $\begin{array}{l}\text { Coherence Principle: } \\
\text { Students learn better } \\
\text { when extraneous words, } \\
\text { pictures, sounds are } \\
\text { excluded rather than } \\
\text { included. }\end{array}$ & $\begin{array}{l}\text { Multimedia presentations } \\
\text { should be focus, clear, and } \\
\text { concise. Presentations that } \\
\text { add extraneous information } \\
\text { such as the sound of bell or } \\
\text { whistle with the reason to } \\
\text { increase the student interest } \\
\text { is actually impede the } \\
\text { student's learning and focus. }\end{array}$ \\
\hline $\begin{array}{l}\text { Modality Principle: } \\
\text { Student learns better } \\
\text { from animation and } \\
\text { narration rather than } \\
\text { animation and on- } \\
\text { screen text }\end{array}$ & $\begin{array}{l}\text { The use of words should be } \\
\text { presented as spoken words } \\
\text { or using auditory, rather than } \\
\text { presented as written text to } \\
\text { accompany the graphics. }\end{array}$ \\
\hline $\begin{array}{l}\text { Redundancy Principle: } \\
\text { Students learn better } \\
\text { from animation and } \\
\text { narration rather than } \\
\text { animation, narration, } \\
\text { and on-screen text. }\end{array}$ & $\begin{array}{l}\text { The multimedia presentations } \\
\text { that involve combination of } \\
\text { words and pictures should } \\
\text { present text either in written } \\
\text { form, or in auditory form, but } \\
\text { not in both on a screen. }\end{array}$ \\
\hline $\begin{array}{l}\text { Individuals Difference } \\
\text { Principle: Design effects } \\
\text { are stronger for low- } \\
\text { knowledge learners } \\
\text { rather than for high- }\end{array}$ & $\begin{array}{l}\text { Example of low-knowledge } \\
\text { learners is novice learners } \\
\text { and high-spatial learners are } \\
\text { for visually-style learners. Well- } \\
\text { structured multimedia }\end{array}$ \\
\hline
\end{tabular}

\begin{tabular}{|c|c|}
\hline $\begin{array}{l}\text { knowledge learners and } \\
\text { for high-spatial learners } \\
\text { rather than low-spatial } \\
\text { learners. }\end{array}$ & $\begin{array}{l}\text { presentations should be } \\
\text { created to be more } \\
\text { accessible. }\end{array}$ \\
\hline $\begin{array}{l}\text { Signaling Principle: } \\
\text { Students learn better } \\
\text { when cues that highlight } \\
\text { the organization of the } \\
\text { essential material are } \\
\text { added. }\end{array}$ & $\begin{array}{l}\text { Providing cues to the learner } \\
\text { on how to organize the } \\
\text { materials. }\end{array}$ \\
\hline $\begin{array}{l}\text { Segmenting Principle: } \\
\text { Students learn better } \\
\text { when a multimedia } \\
\text { lesson is presented in } \\
\text { user-paced segments } \\
\text { rather than as a } \\
\text { continuous unit. }\end{array}$ & $\begin{array}{l}\text { The modules or exercise } \\
\text { provided are presented } \\
\text { sequentially and logically } \\
\text { from easy to hard. Allows the } \\
\text { user to control the } \\
\text { presentation. }\end{array}$ \\
\hline $\begin{array}{l}\text { Pre-training Principle: } \\
\text { Students learn more } \\
\text { deeply when they } \\
\text { receive pre-training in } \\
\text { the names and } \\
\text { characteristics of key } \\
\text { components. }\end{array}$ & $\begin{array}{l}\text { Create low level } \\
\text { exercise/problem solving to } \\
\text { the learners before they can } \\
\text { proceed to the larger and } \\
\text { more complicated exercise. }\end{array}$ \\
\hline $\begin{array}{l}\text { Personalization Principle: } \\
\text { Student learns better } \\
\text { from a multimedia } \\
\text { presentation when the } \\
\text { words are in } \\
\text { conversational style } \\
\text { rather than in formal } \\
\text { style. }\end{array}$ & $\begin{array}{l}\text { Example of conventional } \\
\text { style text is Comic Sans. }\end{array}$ \\
\hline $\begin{array}{l}\text { Voice Principle: } \\
\text { Student learn better } \\
\text { when the words in a } \\
\text { multimedia message } \\
\text { are spoken by a friendly } \\
\text { human voice rather } \\
\text { than a machine voice }\end{array}$ & $\begin{array}{l}\text { Create a teacher character } \\
\text { in multimedia presentation. }\end{array}$ \\
\hline $\begin{array}{l}\text { Image Principle: } \\
\text { Student does not } \\
\text { necessarily learn more } \\
\text { deeply from a } \\
\text { multimedia presentation } \\
\text { when the speaker's } \\
\text { image is on the screen } \\
\text { rather than not on the } \\
\text { screen. }\end{array}$ & $\begin{array}{l}\text { Use a voice of teacher } \\
\text { character. No image of } \\
\text { teacher is presented. }\end{array}$ \\
\hline
\end{tabular}

Each of the principle can be considered in combination as A4LV content. Next section details this connection. An example of works that adapt the multimedia learning principles is[15]. He has proposed a conceptual model to design learning materials for small screen application. Similarly, Domagk, Schwartz, and Plass (2010), also utilized multimedia learning principles in designing an integrated model of multimedia interactivity called INTERACT. The aim of this model is to clarify the concept of interactivity and further acts as a reference to other studies in developing interactive multimedia presentation. 
There are four components underlying this model, which are user, learning environment, system of connection, and concepts to make up the interactivity. This shows the importance of considering multimedia aspects in designing multimedia learning content to make it usable to the intended user.

In the context of this study, it was found that all principles are applicable to be applied in AC4LV at a time since AC4LV is multimedia learning content application. However, the connection must be carefully applied since the intended users are low vision learners in order to make it usable in terms of information accessibility, navigation ability, and pleasure. Next section discusses on methodology utilized in conducting this study.

\subsection{METHODOLOGY}

In this study a series of activities were carried out, as shown illustratively in Figure 3. The figure explains that this study involves three phases of activities which are (i) requirement analysis (ii) reviews on literatures, and (iii) prototype development[3]. The activities involved in the first phase are requirement analysis, which implicates that previous studies regarding the problems faced by the low vision learners were reviewed. Also, they are interviewed and their learning activities were observed in order to identify their needs in learning. Phase two involves reviews and elicitation on literatures in which the documents related to Multimedia Learning Theory were studied. From this phase, data regarding the principles of Multimedia Learning Theory were reviewed, and then the second objective of the study was achieved. The third phase is prototype development, in which the development process as illustrated in Figure 10 are employed based on the data gathered in phase one and phase two. At this stage, this study has achieved its third objective. Having finished the third phase, the whole objective of this study is achieved.

Going in-depth into the development process of AC4LV, it involves three phases which are preproduction, production, and post production (Figure 4). In the first phase, 10 steps have to be implemented. In developing AC4LV it is important to involve users and experts before the development of AC4LV were begun. At this phase, requirements of users were investigate by interviewing the teachers regarding the needs of low vision learners to suit with the actual content of AC4LV. Also, the low vision learners were involves to gather the input and comments in terms of the design of AC4LV.

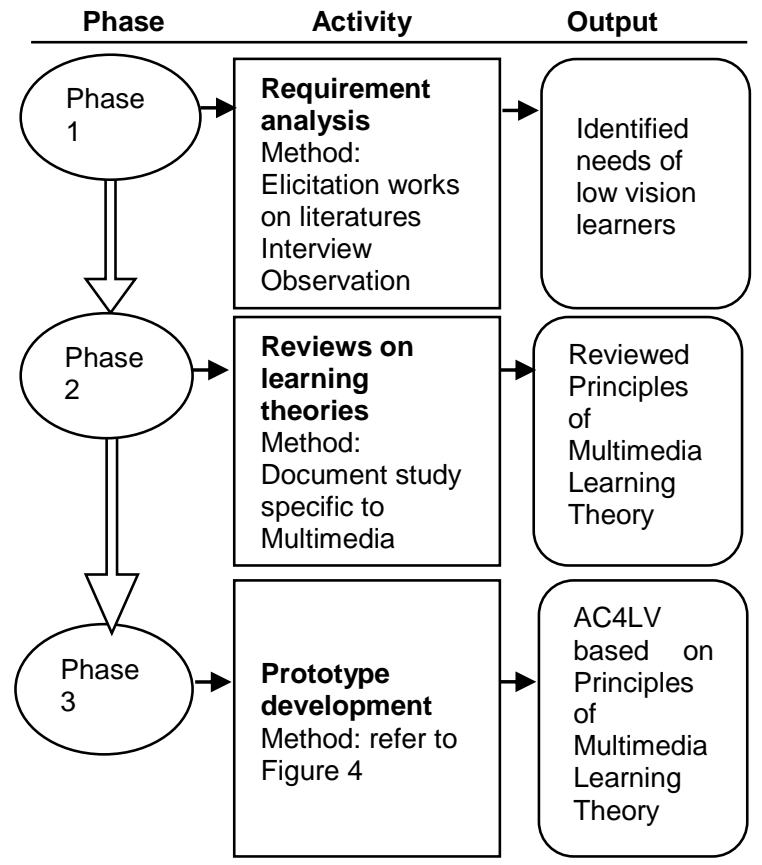

Figure 3 Summary of activities

Reviewed Principles of Multimedia Learning Theory was utilized as a design guideline prior to start the interview. All this input is important in preparing the script and storyboard of AC4LV. This is called as User Centered Design (UCD) approach as demonstrated in Figure 5 and figure 6. The initial design of AC4LV has been demonstrated to the low vision learners and teachers. Their comments and suggestion has been utilized as useful input to develop the AC4LV. Having finished the 10 steps in pre-production phase, the development of AC 4LV was started by utilizing Adobe Flash as the basement of the development tool. While, Sound Forge was used to record and edit the sound as well as Adobe Illustrator was utilized to design all the characters. At post production phase, editing and quality checking were performed which also involves the actual users and their teachers. It was done until they satisfied and finally the AC4LV was packaged in the form of DVD prior to test the experience of using it in the future works of this study. 


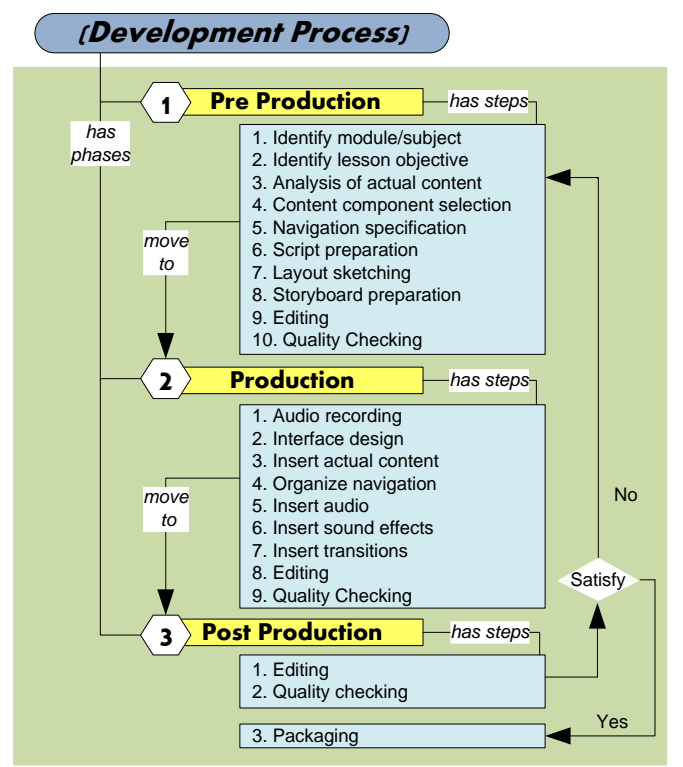

Figure 4 Development process of AC4LV

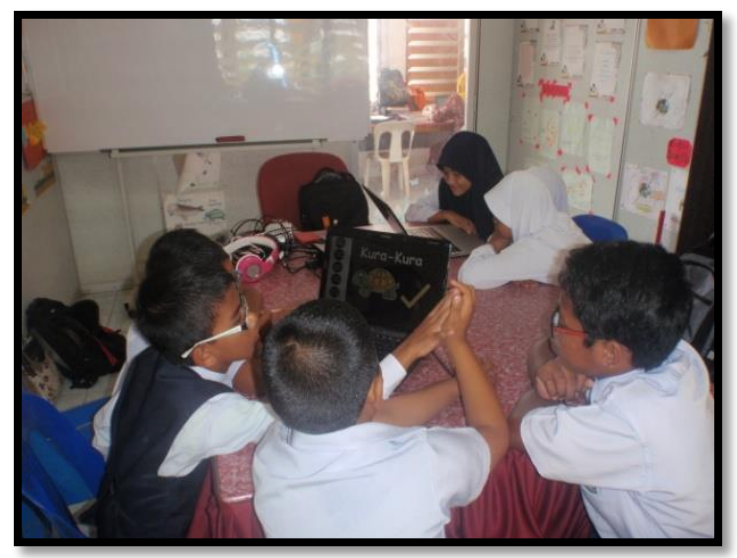

Figure 5 Applying UCD approach with low vision learners

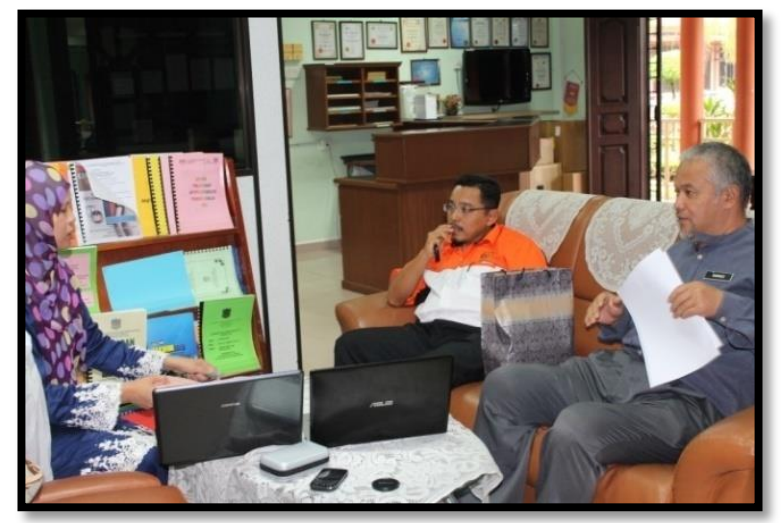

Figure 6 Applying UCD approach with teachers as expert
The results are discussed detail in the next section together with the snapshots of the prototype.

\subsection{FINDINGS AND DISCUSSION}

Multimedia Learning Theory has been utilized as a reference and guidance in designing the content of AC4LV based on the identified user needs. Therefore, this section discusses on the findings gathered in phase three on how the Principles of Multimedia Learning Theory applied in AC4LV based on the low vision needs in information accessibility, navigationability, and pleasure.

3.1 Multimedia Learning Theory Mapped to AC4LV Based on Information Accessibility, Navigationability, and Pleasure

\section{Information Accessibility}

Information accessibility refers to the characteristics of AC4LV that enable the low vision learners to capture the learning content presented to them. Such of the Principles of Multimedia Learning Theory that able to be adapted to achieve the information accessibility aspect is:

\section{Multimedia}

AC4LV combines texts and graphics to be displayed on a screen in delivering the contents. In achieving information accessibility, the color of information (i.e. texts and graphics) that are presented through multimedia principle has to be contrast with the background. Combination of black and white is a good pair of them (Figure 7).

\section{Spatial Contiguity}

For the low vision learners placing text under the graphic is more efficient compared to placing text within the graphic. This facilitates them to differentiate between texts and graphics (Figure 7).

\section{Personalization}

Font face utilize in AC4LV is conventional style (e.g. Comic Sans) which is personally more suitable to low vision children (Figure 7). 


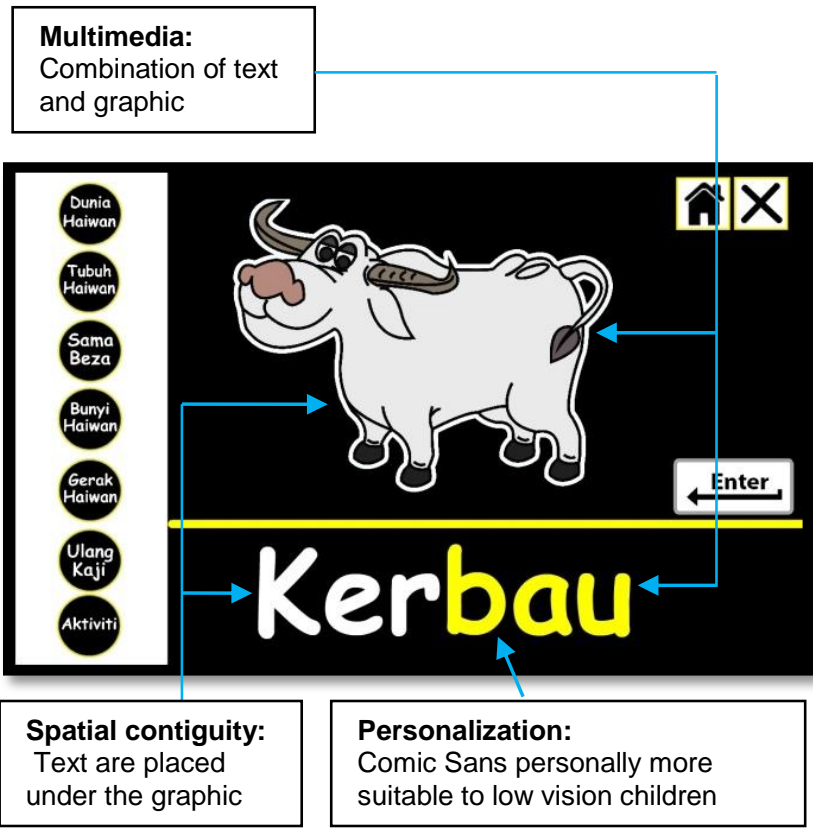

Figure 7 Multimedia, spatial contiguity, and personalization applied in AC4LV

\section{Temporal Contiguity}

In AC4LV, texts and graphics are presented simultaneously on a screen. This make easy for them to capture the knowledge presented on the screen (Figure 8).

\section{Coherence}

No extraneous texts, graphics and sounds included in AC4LV. This presentation assists the low vision learners to have focus, clear and concise in their learning activities. Superfluous multimedia elements are actually impeding their learning focus (Figure 8).

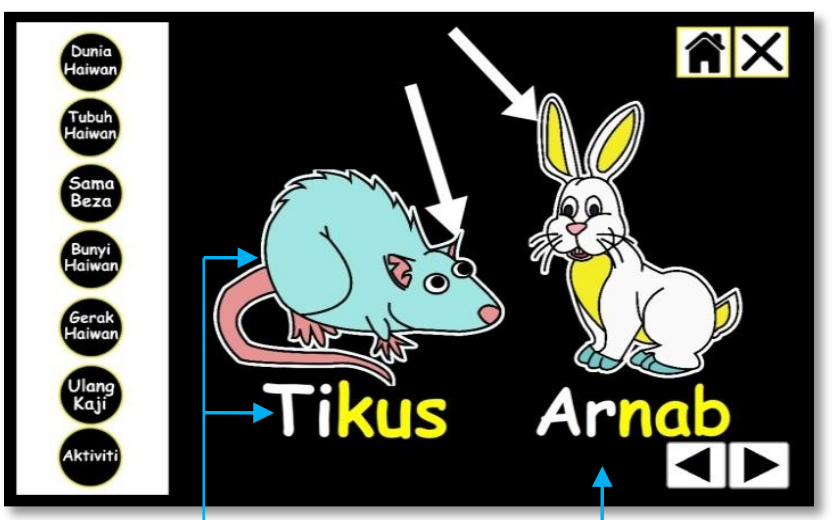

Temporal contiguity: Texts and graphics are present simultaneously on the screen

Coherence:

No extraneous texts, graphics, and sounds displayed.

Figure 8 Temporal contiguity and coherence adapted in AC4LV

\section{Navigationability}

Navigationability means the characteristics of AC4LV that able to assist the low vision learners in navigating the courseware.

\section{Segmenting}

The topics and activities in AC4LV are present logically from easy to hard. AC4LV allows the low vision learners to control the presentation by providing section separators and navigational button (Figure 9 and Figure 10).

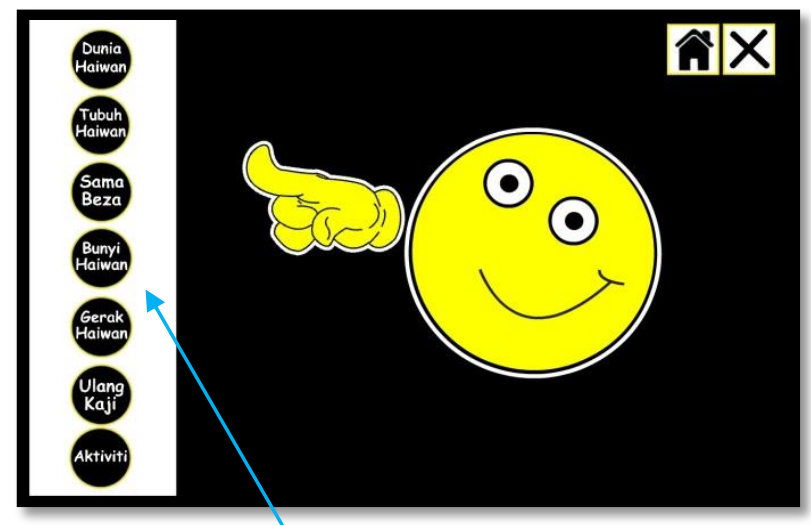

Segmenting:

Navigational button are provided by

implementing information accessibility

Figure 9 Segmenting in AC4LV

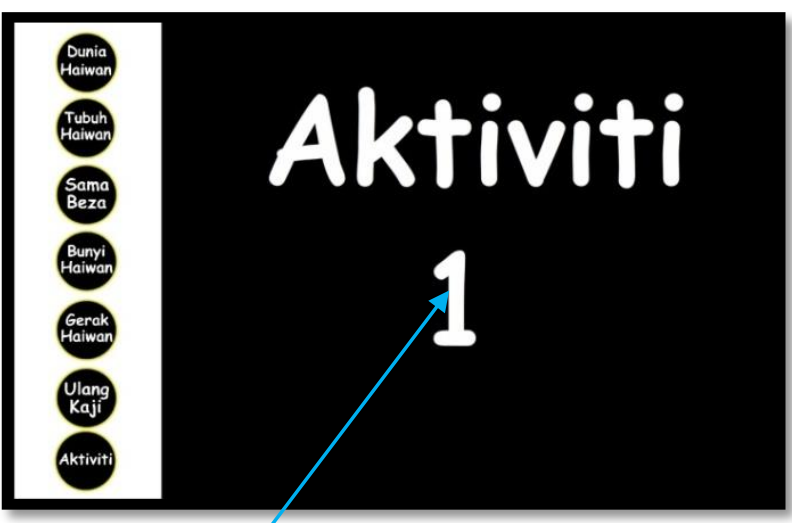

Segmenting:

Section separators are provided

Figure 10 Segmenting in AC4LV

\section{Signaling}

AC4LV provide guidance for the low vision learners to navigate the courseware. Also, demonstrations are provided for them before start doing activities. Clear instructions make easy for low vision learners to navigate the activity part (Figure 11). 


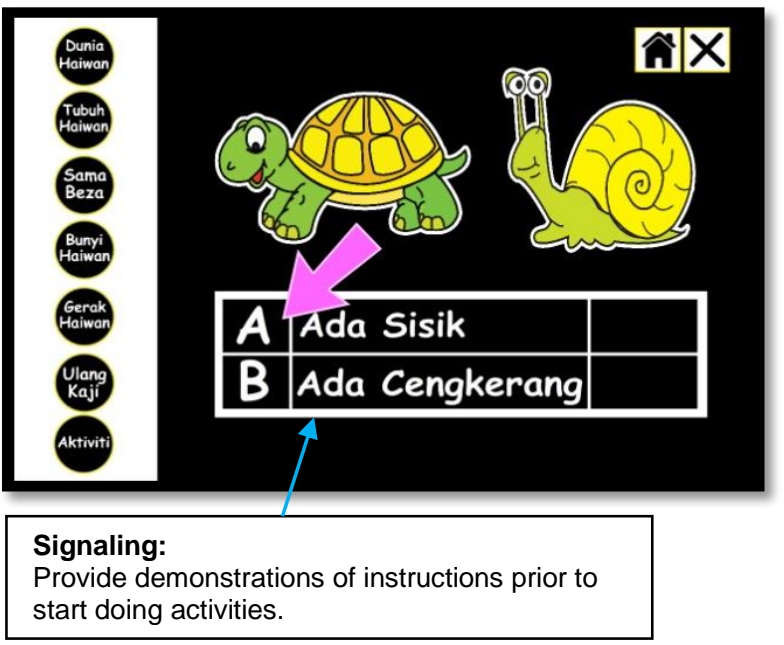

Figure 11 Signaling in AC4LV

\section{Pleasure}

Pleasure in AC4LV means the characteristics of AC4LV that make the low vision learners feel amused, enjoy, and release as well as have no pressure during learning activities (Ariffin, 2009). This could be seen in modality:

\section{Modality}

This could be seen when "Smiley" character briefing and outline the learning outcomes in narration to catch the low vision learners' attention in starting the learning activities rather that provide animation and on-screen texts which actually makes them confuse and bored (Figure 12).

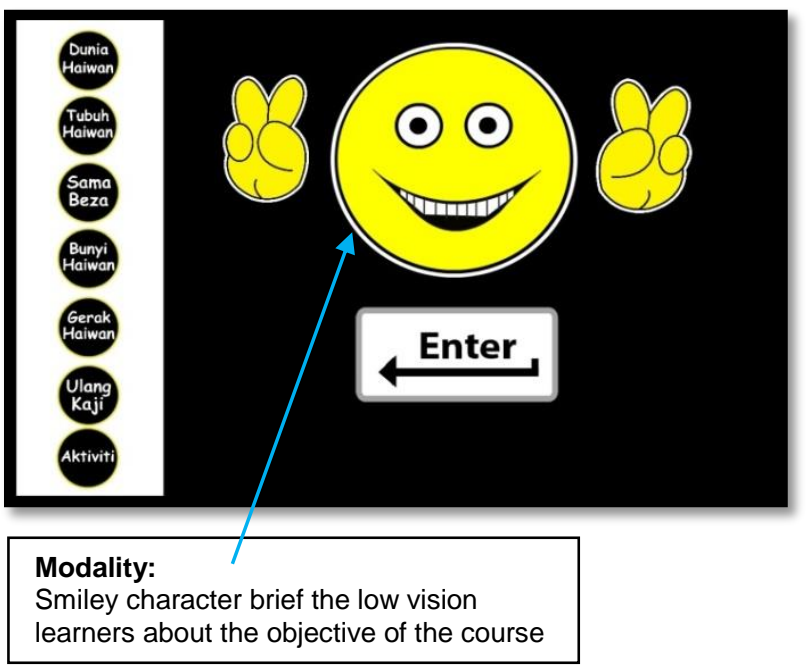

Figure 12 Modality mapped to AC4LV

\section{Redundancy}

No redundancy in AC4LV. This explains graphics and texts are present simultaneously with auditory explanation. Animations and musical are show concurrently with no text elements. This could enhance the learners' attention (Figure 13).

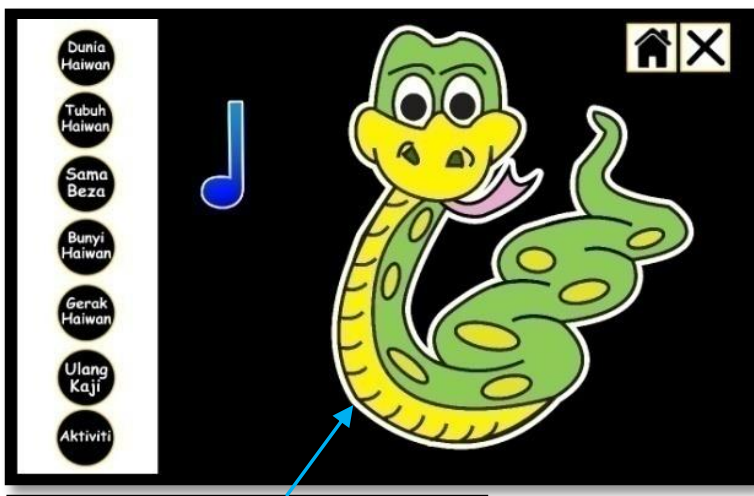

Redundancy:

Animations and musical are show

concurrently with no text

Figure 13 Redundancy principle applied in AC4LV

\section{Individual Difference}

This is proven through sound effects provided in AC4LV which specially designed for novice and low spatial learners. Sound effects could enhance the learners understanding (Figure 14).

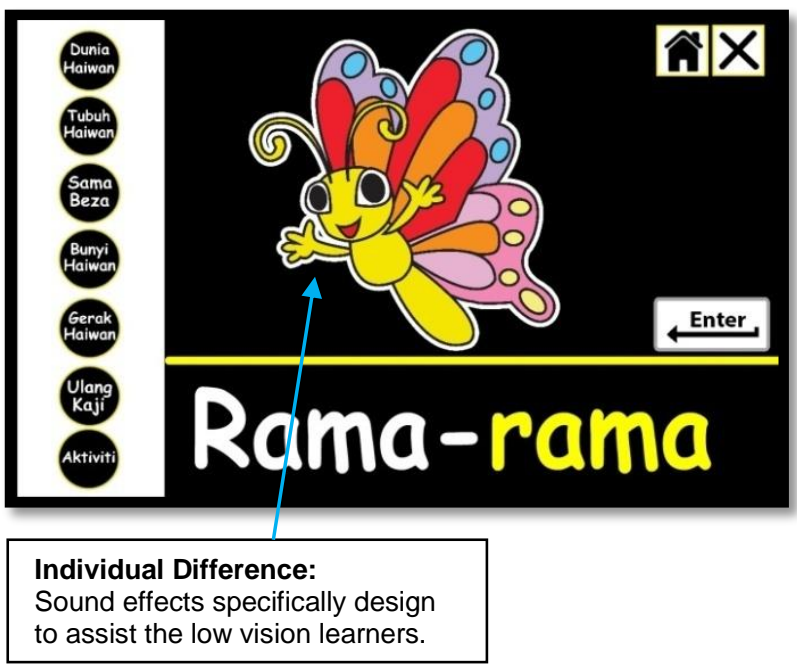

Figure 14 Individual difference mapped to AC4LV

\section{Pre-training}

AC4LV form low level activities (e.g. two option of answers) before proceeding to the complicated exercise (problem solving activities). Pre-training 
influences the low vision learners to have no pressure in doing activities (Figure 15).

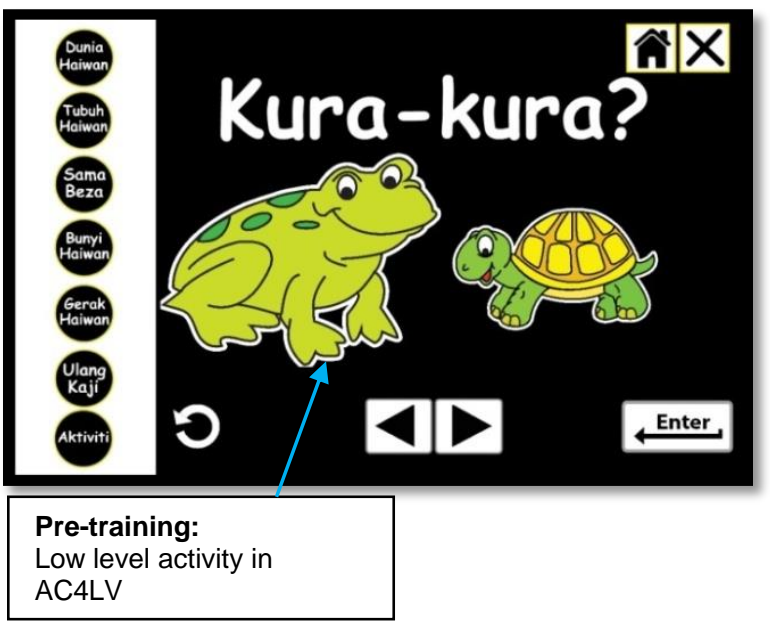

Figure 15 Pre-training applied in AC4LV

\section{Voice}

All words in AC4LV are spoken by friendly women voice with proper intonation which could be a magnet for the low vision learners to stay focus on screen rather than uses machine voice which quiet bored (Figure 16).

\section{Image}

No image of teacher is presented in AC4LV. Only voice and character appears in the show. This assists the low vision learners to learn without facing crowded interface (Figure 16).

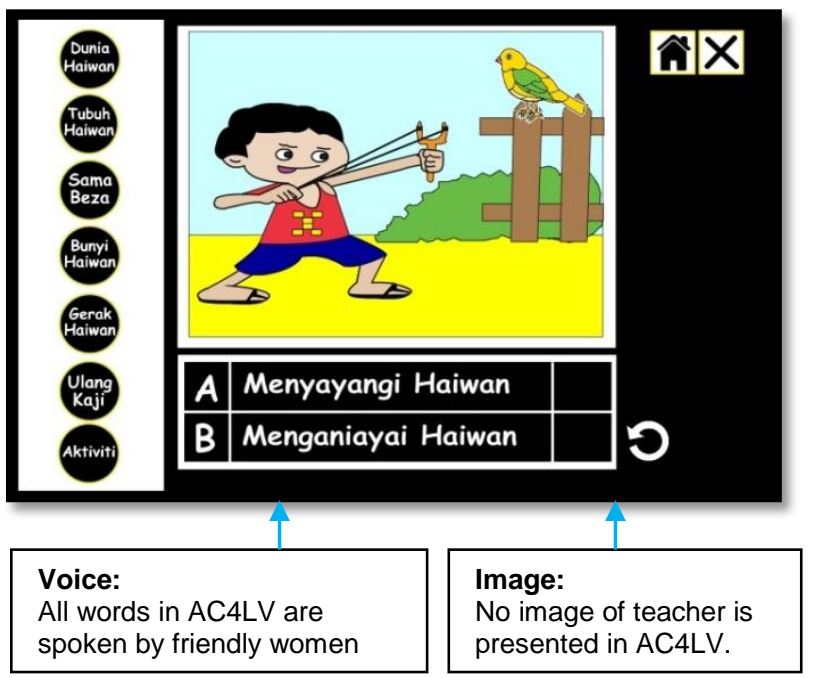

Figure 16 AC4LV Interface

\subsection{CONCLUSION AND FUTURE WORKS}

Overall, this study has achieved it objective to develop a courseware that specifically designed for low vision learners based on Multimedia Learning Theory by concerning the needs of low vision learners in learning. Through interview and observation it was found that information accessibility, navigationability, and pleasure is the main aspects that has to be concern by the developer prior to develop a content application for low vision learners particularly courseware. Besides the user needs, it was significance for this study to consider Multimedia Learning Theory as the guidance in designing the content of AC4LV. Findings for this study indicate that all of the principles of Multimedia Learning Theory are applicable to be mapped to AC4LV as well as fulfill the user needs. Future works of this study is to test the experience of using AC4LV among the low vision learners from age nine to twelve in terms of information accessibility, navigationability, and pleasure aspects.

\section{Acknowledgement}

The researchers wish to thank to the Primary School of Jabi (Visual Impairment Integration) and Special Primary School of Alma (Visual Impairment) for their cooperation participating in this study. This study also has been financed by Universiti Utara Malaysia (UUM), Malaysia and Ministry of Higher Education, Malaysia. The authors gratefully acknowledge both of the credibility organizations'.

\section{References}

[1] A. Nurulnadwan, A. M. Ariffin, S. Siti Mahfuzah, and J. Saifullizam. 2013. Preliminary investigation on Creative Educational Content for Visually-Impaired (VI) Learners. In Advances in Visual Informatics. 3rd ed. no. Vi, H. Badioze Zaman, P. Robinson, O. Patrick, T. K.Shih, and S. Velastin, Eds. Switzerland: Springer International Publishing. 408-417.

[2] J. Khadka, B. Ryan, T. H. Margrain, J. M. Woodhouse, and N. Davies. 2012. Listening to Voices of Children with a Visual Impairment: A Focus Group Study. Br. J. Vis. Impair. 30(3): 182-196.

[3] A. Nurulnadwan, M. R. Nur Hazwani, and A. M. Ariffin. 2011. Visually Impaired Children's Acceptances on Assistive Courseware. Am. J. Appl. Sci. 8(10): 1019-1026.

[4] A. Nurulnadwan, A. M. Ariffin, and S. Siti Mahfuzah. 2014. Critical Analysis in Proposing A Conceptual Design Model Of Assistive Courseware For Low Vision (AC4LV) Learners. Int. J. Comput. Appl. 92(10): 18-25.

[5] J. M. Aljaam, A. Jaoua, S. AlHazbi, A. Hasnah, A. Karime, and A. A. Elsaddik. 2011. An Assistive Computerized System with Tangible User Interfaces for Children with Moderate Intellectual and Learning Disabilities. Int. J. Emerg. Technol. Learn. 6(S2): 11-19.

[6] Z. A. Shaffiei, S. R. Hamidi, N. T. Jauhari, and N. Osman 2014. Requirement Analysis of E-Content for Visual Learners. Int. J. Emerg. Technol. Learn. 9(1): 78.

[7] A. Nurulnadwan, A. M. Ariffin, J. Mohd Saifullizam, and S. Siti Mahfuzah. 2014. A Comparative Analysis on Conceptual Design Model of Assistive Courseware (AC) 
for Visually-Impaired Learners (AC4VI). Aust. J. Basic Appl. Sci. 8(4): 75-80.

[8] A. S. Drigas and R. loannidou. 2013. Special Education and ICTs. Int. J. Emerg. Technol. Learn. 8(2): 41-47.

[9] R. E. Mayer. 2001. Multimedia Learning. New York: Cambridge University Press.

[10] R. E. Mayer. 2010. Applying the Science of Learning to Medical Education. Med. Educ. 44(6): 543-549

[11] P. E. Doolittle. 2002. Multimedia Learning: Empirical Results and Practical Applications. Proc. Irish Educ. Technol. Users' Conf. 1-3.

[12] R. E. Mayer, J. Heiser, and S. Lonn. 2001. Cognitive Constraints on Multimedia Learning: When Presenting More Material Results in Less Understanding. J. Educ. Psychol. 93(1): 187-198.
[13] R. E. Mayer. 2008. Applying the Science of Learning: Evidence-Based Principles for the Design of Multimedia Instruction. Am. Psychol. 63(8): 760-769.

[14] R. E. Mayer and R. Moreno. 2003. Nine Ways to Reduce Cognitive Load in Multimedia Learning. Educ. Psychol. 38(1): 43-52.

[15] D. Churchill. 2011. Conceptual Model Learning Objects and Design Recommendations for Small Screens Key Concepts and Issues. Educ. Technol. Soc. 14(1): 203-216.

[16] S. Domagk, R. N. Schwartz, and J. L. Plass. 2010. Interactivity in Multimedia Learning: An Integrated Model. Comput. Human Behav. 26(5): 1024-1033. 